\title{
CORPORATE GOVERNANCE AND COMPANY PERFORMANCE IN ITALY: CORPORATE LAW AND REGULATION PERSPECTIVE
}

\author{
Carlo Caserio *, Sara Trucco ** \\ * Corresponding author, Università degli Studi eCampus, Italy \\ Contact details: Faculty of Economics, Università degli Studi eCampus, Via Isimbardi, 10, 22060, Novedrate (CO), Italy \\ ** Faculty of Economics, Università degli Studi Internazionali di Roma, Italy
}

\section{OPEN ACCESS}

How to cite this paper: Caserio, C., \& Trucco, S. (2019). Corporate governance and company performance in Italy: Corporate law and regulation perspective. Corporate Law \& Governance Review, 1(1), 24 - 35.

http://doi.org/10.22495/clgrvlilp3

\section{Copyright $@ 2019$ The Authors}

This work is licensed under a Creative Commons Attribution 4.0 International License (CC BY 4.0). https://creativecommons.org/licens es/by/4.0/

ISSN Online: 2664-1542

Received: 23.03 .2019 Accepted: 14.05.2019

JEL Classification: G30, L25 DOI: $10.22495 /$ clgrvlilp3

\begin{abstract}
This paper proposes an extensive analysis of corporate governance and corporate board practices in Italy, under different perspectives. First of all, through a literature review, the research aims to analyze the main effects of laws and regulations on corporate board practices in the Italian setting by taking into account the most important corporate board models in different types of companies. This study also highlights the different functions and responsibilities assigned to the boards, bodies and boards' members, according to the governance system implemented - classic/traditional, dualistic, monistic. For each of these systems, the main issues are presented and the most important critical points are illustrated. Regarding the functions and the responsibility of the board members, the link between the board governance and company performance is discussed on the basis of the main literature, as well as the laws concerning the participation of women to the boards' activities. Furthermore, the effects of gender diversity on company performance is analysed taking into account the main studies on this topic. Finally, the paper presents some conclusions and future research areas on the aforementioned topics: it proposes future empirical analysis on the effects that different governance systems, different board compositions and different roles of directors, as required by the law, may have on the performance of listed/unlisted companies and on family/non-family companies.
\end{abstract}

Keywords: Corporate Governance, Company Performance, Governance Systems, Corporate Board Practices

\section{INTRODUCTION ${ }^{1}$}

The issue of corporate governance in Italy is particularly interesting, because main problems are linked to the potential conflicts of interest between principal and principal, which is a well-known critical issue in the literature, observed in several fields, such as the family firms (Calabrò, Campopiano, \& Basco, 2017), the financial flexibility in transition economies (Estwick, 2016), the stock price effects (Sun, Yuan, Cao, \& Wang, 2017) and in

${ }^{1}$ Although the article is the result of joint opinions and analyses, the paragraphs 2.1. Introduction and 2.2. Legal overview of the Corporations in Italy are attributed to Carlo Caserio, whereas the paragraphs 2.3 Analysis of Corporate Board Practices in Italy, 2.4 Analysis of a Link between Board Governance and Company Performance and 2.5 Conclusion are attributed to Sara Trucco. several countries. Indeed, this conflicts arise because the controlling and the minority shareholders have different information and aims (Melis \& Zattoni, 2017). Italy adopted the Code of Self-Regulations set by the Corporate Governance Committee of Italian Stock Exchange in 1999 (Elshandidy \& Neri, 2015). The changes that affected the Italian laws emphasized the relevance of the corporate governance and independent directors in order to reduce the concentrated ownership and other weaknesses in the Italian firms.

Furthermore, the laws introduced for regulating limited liability companies and limited companies, demonstrate the high attention paid by regulators to these two types of companies, with the aim to promote and stimulate the entrepreneurial activities in Italy, in addition to protect the investors and the stakeholders' interest. However, the choice between a classic, a monistic or a dualistic model, introduced 
by the law, raises some questions about the effective adoption of these systems in Italy.

However, very few studies are carried out on this issue in the Italian setting and there is room for further investigations. This paper analyses the corporate board in the Italian setting, therefore, its aim is to shed some lights on the laws and regulations that affect the corporate board and the corporate board practices in Italy.

The remainder of this paper is structured as follows: the second section discusses the laws and regulations that affect the corporate board in Italy, by highlighting the different types of companies, the models of corporate governance and the functions of the board; the third section discusses the corporate board practices in Italy, by focusing on the board members and the role of women on the board; the fourth section focuses on the link between board governance and company performance and the fifth section presents conclusions around the main topic of this paper and proposes some suggestions for future research.

\section{LEGAL OVERVIEW OF THE CORPORATIONS IN ITALY}

\subsection{Types of companies}

The main distinction we can recognize in Italy is between partnerships (società di persone, literally, personal companies) and limited companies (società di capitali, literally, capital companies). In Italy we find several types of partnerships:

S.s.);

- the "simple" partnership (società semplice,

- the general partnership (società in nome collettivo, S.n.c.);

- the limited partnership (società in accomandita semplice, S.a.s.).

The companies belonging to this first typology do not have legal personality and have an imperfect patrimonial autonomy. This means that the partners, along with the company itself, have unlimited and joint responsibility for the debts and other liabilities of the company. The partners respond with all their assets, present and future, and solidary, in such a way that the creditor of the company can, at its option, turn to any of the partners and claim from him the fulfillment of the entire obligation.

In general, in partnerships each member has the power to administer the company and he cannot transfer his share of participation in the company without the consent of the other shareholders, either by agreement between the Parties or for cause of death. In the event of succession, beneficiaries are not entitled to become part of the company but have only a credit right equal to the effective value of the company share in succession. In case they wish to become society partners, the consent of the other members of the company is required, in addition to the consent of the heirs themselves. However, the Italian law allows to define clauses for the free transferability of the share, by means of agreement between the Parties that regulate otherwise the transfer of the share in case of succession.

Differently from the partnerships, limited companies have legal personality, which means that only the company is responsible for its liabilities (with some exceptions). In Italy we find the following types of limited companies:

- the public limited companies (società per azioni, S.p.A.);

- the limited liability companies (società a responsabilità limitata, S.r.l.);

- the limited partnership on shares (società in accomandita per azioni, S.a.p.A.);

- the simplified limited liability companies (società a responsabilità limitata semplificata, S.r.l.s.).

These companies are organizations of persons and means for performing a joint business activity, endowed with full financial and patrimonial autonomy. This implies that only the society with its patrimony responds to social liabilities. The responsibility of partners is, instead, limited to the capital they conferred, so that they do not assume any personal obligation, not even subsidiary, for the social liabilities (except for some exceptions provided by law).

The system of limited companies has been deeply reformed with the aim to increase their competitiveness on domestic and international markets. One of the effects of this reforming is to increase the private autonomy of the companies, which can regulate the development of their activity, starting from the very first years, through memorandum and instrument of incorporation.

As we will see later on, the shareholder does not have direct power of administration and control of the company, but can express his vote at the partners meeting, in doing so participating to the appointment of the directors and supervisory board. of course, the shareholder himself may be appointed as director, assuming the relative responsibility.

In a first analysis, the limited company usually operates through the presence of three bodies: a) the shareholders' meeting, which has the main competence to take the most important decisions for the company; b) the directors, who are responsible for managing the company and implementing the corporate purpose; c) the statutory auditors, supervisory and supervisory bodies who control the activities of the directors.

Another important distinction recognizable in Italy is between government-owned companies and private companies. The first category includes companies partially or totally owned by the Ministry of Economy and Finance; these companies are generally of public interest, such as electricity transmission, gas distribution, transportations, financial services. However, even if these companies are State-controlled, they are still open to private competition.

Furthermore, the distinction between family and non-family business is very relevant in Italy. According to a recent observation conducted by the AIDAF - Italian family business, Associazione Italiana delle Aziende Familiari, about the $85 \%$ of the total number of companies - both large and smallmedium size - is family-owned (http://www.aidaf.it/ aidaf/le-aziende-familiari-in-italia/);moreover, family businesses represent around $60 \%$ of the Italian shareholding market. 


\subsection{Main reforms}

Since the entry into force of the Royal Decree No. 262 of March 16, 1942 (Civil Code), the civil provisions that regulate the partnerships have not undergone substantial changes. An attempt to update the reform, aimed primarily at simplifying the corporate structures, was taken into consideration by the Rovelli Commission in 1999 but due to the end of the legislature and to the most urgent needs to reform corporate law in relation to limited companies and cooperative companies, this update was not applied.

The Law 262/2005 (Savings Law) states that:

- the members of the board of Directors are elected on the basis of lists presented by shareholders which represent a part of share capital.

- minority shareholders are represented in the board through a specific list. This provision, at least on a theoretical level, could be useful for corroborating the independence of the controlling members from the independent directors.

On the other side, the Executive branch of the new legislature, through the Law No. 366 of 3 October 2001, committed itself in issuing one or more legislative decrees to reform the limited companies and the cooperative companies. As a consequence, the Legislative Decrees No. 5 and No. 6, of 17 January 2003, were issued (Buonocore, Bassi, \& Pescatore, 2003). The main general aims of this reform were to:

- adapt the Italian commercial laws to the international market models; needs;

- simplify the discipline to meet the economic

- promote the founding of new companies and the economic initiative;

- modify the civil and processual aspects concerning the discipline of the main models of limited companies;

- reorganize the cooperatives;

- modify the regulation of groups of companies;

- increase the statutory autonomy of limited companies.

In the Italian setting, corporate governance could be defined as a set of mechanisms, procedures, institutions and rules through which assure the satisfaction of potential contrasting interests of each stakeholder (Airoldi, 1993). In Italy corporate governance is characterized by a large ownership concentration and a low protection of minority shareholders (Barker, 2010). Indeed, to solve this problem and to protect minorities, in 1998 a reform of corporate governance was implemented (the Draghi Law). Corporate control is carried out by "industrial families" through pyramidal control mechanisms which allow controlling families to keep control over the group and also over the majority of shares in the firms belonging to the group. In doing so, the amount of capital invested by the "industrial families" is minimized. Furthermore, companies can issue shares with limited or without voting rights for increasing capital without losing the control of the parent companies (Drago, Millo, Ricciuti, \& Santella, 2015; Melis, 2000; Zattoni, 1999).

Dyck and Zingales (2004) argue that in Italy private benefits of control are higher than in other countries such as France, Germany and the UK. In the Italian context, indeed, there is a lower investor protection, poorer accounting rules, lower tax compliance and a less independent press (Dyck \& Zingales, 2004)

\subsubsection{Limited liability companies}

Regarding the limited liability companies, the main effects of the reform were the increased statutory autonomy and the consequent lower level of detail required for the instrument of incorporation. When allowed, if only the interests of the members are involved, the legislator leaves ample space to the needs of shareholders and allows different options (for example, in terms of administration and control). The reform also allowed companies to access new financing techniques and to have higher autonomy in defining the aspects and the transfer policies related to the partners quotas, as well as the criteria for the injection of capital by the partners.

With the Law No.99/2013 other important modifications occurred on the regulation of limited liability companies, to further promote the business initiatives. Before this law, two variants of limited liability companies did exist:

- the first was the "simplified" limited liability companies, where the Partners had to be natural (not legal) persons younger than 35 years old, where the administrators had to be selected among the Partners and the quotas could not be transferred to Partners elder than 35 years old;

- the second was the limited liability companies with "reduced capital", where the only prerequisite was that Partners had to be natural (not legal) persons without any age requirement.

Both variants of limited liability company had to have a social capital comprised between 1 EUR and 9.999,00 EUR, to be submitted entirely with cash contributions.

The Law No.99/2013 "merged" the two variants, extending the incentives that before were reserved only to the "simplified" limited liability companies, to all the partners (natural persons). Therefore, after this reform, the "simplified" limited liability company remains as the only variant but without any age limit required for Partners, not even for transferring the quotas with each other; also, the requirement to appoint the administrator among the Partners has been abolished.

\subsubsection{Limited companies}

Regarding the limited companies, one of the most important effects of the 2003 reform was the introduction of the distinction between "closed" limited companies, which are self-financing companies that have no access to the risk capital market, but which mainly rely on debt financing, and "open" limited companies, which, in turn, can be further distinguished in "open" companies with access to the risk capital market and "open" companies listed on a stock exchange (Di Sabato, 2011). The reform also allowed limited companies to be formed as a single-partner company (società unipersonale) and to access to several financial instruments - in addition to shares and bonds. Furthermore, the reform brought a weakening of the 
powers of the assembly, but an increase of that of the administrative body; moreover, limited companies benefit from the constitution of assets destined for a specific business. One of the most important effects of the Legislative Decrees No. 5 and No. 6, of 17 January 2003 is to allow limited companies to choose which of the following administration and control systems they wish to adopt: classic system, dualistic system, monistic system.

Next to the traditional structure, founded on the administrative body, eventual delegated bodies and board of statutory auditors, the legislator has introduced the German dualistic system, based on a supervisory board, appointed by the shareholders assembly, and a management board, made up of different persons nominated by the supervisory board, as well as the monistic system of Anglo-Saxon inspiration, in which control over the board of directors is exercised by a committee for management control, appointed within the board itself.

\subsection{Classic or traditional system}

In this model the administrators are appointed by the shareholder assembly, except the first ones, which are nominated in the by-laws (art. 2383 Civil Code, paragraph 1). The management of the company is a task exclusively of the administrators, who must perform any necessary action to achieve the business object (art. 2380-bis, comma 1, Civil Code). This system is applied in absence of a different statutory choice of the company, and it is based on the distinction between the management board - which can be the board of Directors or the CEO - and the control board - which is the board of statutory auditors.

Figure 1. Traditional governance system (own elaboration)

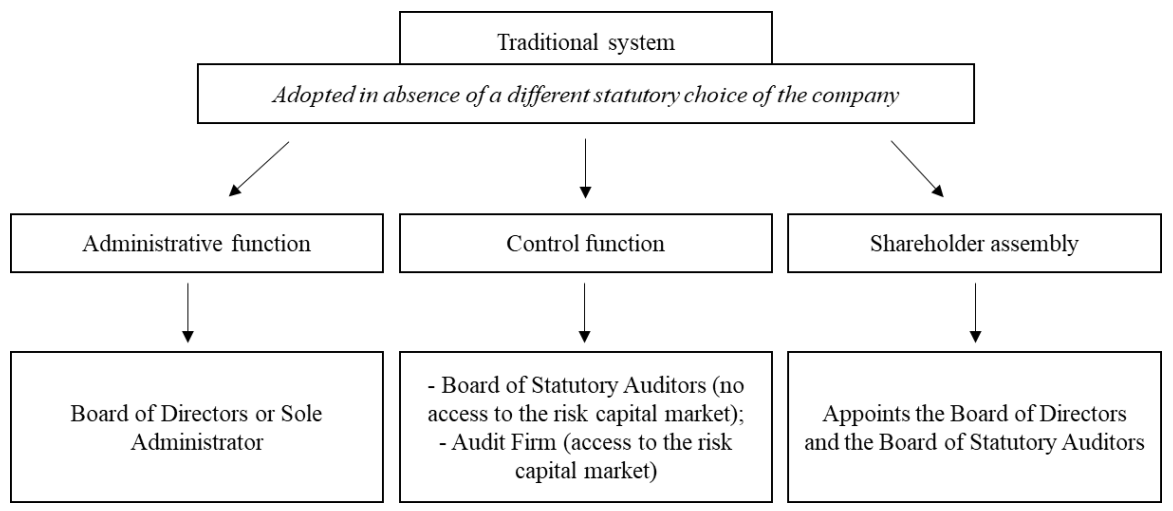

This last body does not perform the audit of accounts, being this role assigned mandatorily to a certified auditor or, in case of companies which access the capital risk market, to an audit firm. The classic system, thus, requires the presence of an administrative board, which is controlled by a board of statutory auditors and, with regard to the control of accounting values, by an auditor or an audit company. If a company does not access the risk capital market and does not need to present consolidated financial statement, then the board of statutory auditors can be appointed to carry out the auditing, but, in this case, all the members of the board need to be registered as certified auditors. Otherwise, the registration is mandatory for at least one effective component and for an alternate component. Others must be chosen among the members of the professional associations, identified by decree of Minister of Justice, or among tenured university professors in economic and juridical subjects (Venturi, 2008). In this model, the directors are elected by the ordinary shareholders' meeting, except for the first ones which are named in the instrument of incorporation. The management of the company is an exclusive responsibility of the directors, who carry out all the actions necessary for the implementation of the corporate purpose and this responsibility cannot be shared with other social subjects.
About the control, as specified above, this is attributed to the board of statutory auditors, which perform management control activities consisting in verifying the compliance of directors with the principles of correct administration; in case the board of statutory auditors is competent also for the accounting control, then it has to verify the regularity of the records and documents related to the accounting registration and documentation of management operations. If the board of statutory auditors performs only management control, the accounting control must be conferred to an auditor or an auditing company, registered in the records held by the Ministry of Justice.

In other terms, shortly summarizing the main evidence of the reform, in the traditional system the legislator confers to the directors the exclusive power of management of the company and new powers, such as the emission of bonds and the establishment of separate assets for a specific business. The board of directors may delegate part of its powers to one or more managing directors or to an executive committee: some activities cannot be delegated, such as the presentation of the financial statements draft, the functions related to the reduction of capital (due to losses), the emission of convertible bonds and the approval of the merger and demerger plan. To the board of statutory auditors, the reform requires: a general duty to monitor compliance with the law and the bylaws; 
compliance with the principles of correct administration, with particular regard to the adequacy of the organizational, administrative and accounting structure of the company; concrete functioning of this structure; the obligation to participate in the meetings of all the corporate bodies, to replace the directors in the exercise of the duties imposed on them; to express opinions. The board of statutory auditors must also be heard in occasion of the appointment of the external auditor, with whom it has the obligation to exchange information; moreover, it has the power to convene the shareholders assembly, if it recognizes serious reprehensible facts and there is an urgent need to resolve some problem. In this classical system, all the matters of the accounting control are entrusted to the auditor (natural person or auditing company), to be exercised on the financial statements and on the consolidated financial statements, if drawn up; the auditor is responsible for drawing up the report on the financial statements and for expressing opinions, for example on mergers coming from acquisition with debt. To perform these duties, the auditor can perform inspections, request information to administrators, exchange information with the board of statutory auditors.

\subsection{Dualistic system}

The dualistic system is mainly adopted in Germany, as well as in France, in Netherlands, in Finland and in Italy. In German it is the unique system provided by the law, whereas in Italy, as in France and in Finland the dualistic model is optional and in Netherlands it is mandatory only for large companies (Galgano \& Genghini, 2004) - Figure 2.

Figure 2. Dualistic system (own elaboration)

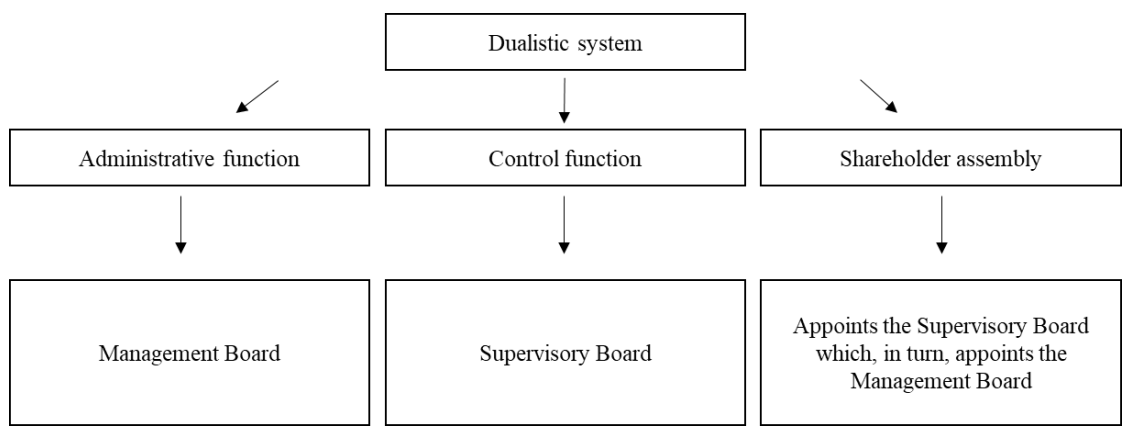

At a first level of analysis it is useful to point out that the dualistic system adopted in German differs both from the Italian and the French, as the German law provides that the administration of the company is articulated into two levels: the Management Board, which operates autonomously and whose members are jointly responsible for the management of the company; the Supervisory Board, which appoints the members of the Management Board, supervises their work and plays an advisory role, being directly involved by the Management Board in decisions that are of paramount importance for the company.

The dualistic system in Italy requires that the control and the administration are carried out, respectively, by a Supervisory Board, appointed by the shareholders' meeting, and by a Management Board, appointed and controlled by the Supervisory Board. The management of the company is thus totally demanded to the Management Board, whereas the control is totally demanded to the Supervisory Board. The accounting control is assigned to an external body, which works together with the two mentioned bodies. The external body performs all the tasks that are generally carried out by the board of Statutory Auditors.

It is important to specify that, in the dualistic model, the functions of company administration are performed collegially by the Management Board, as a consequence, they cannot be entrusted to a sole administrator, although it is possible for the Management Board to delegate some activities.

With regard to the roles covered inside the dualistic model, the functions of the management board correspond, substantially, to those of the board of directors. The difference is that the Management Board is composed by at least two components, not necessarily partners, and it is appointed by the Supervisory Board; it has the exclusive function to manage the company and can nominate delegated administrators or an executive committee (art. 2409-novies Civil Code).

Considered the characteristics of the corporate governance under the dualistic model, it is rather clear that this system is suitable in cases where the holder of the capital is not able, or does not intend, to directly manage the company, so obtaining a separation between the property and the management of the company. This is a system in which the shareholders only establish the lines of the company's economic program and the changes to the structure of the company, in addition to appoint the supervisory board. With these limitations, the dualistic model brings a dissociation between the "property" of shareholders and the "power" of the board. For example, a company which is partially owned by a public entity may find useful to delegate the company management to a board with specific managerial knowledge and capacities, to better interact with the administration. In other terms, this is a model particularly suitable for companies in which management is autonomous and has little interference from shareholders. The shareholders assembly is essentially emptied of its traditional powers. One of the most important and evident effects of the dualistic model is thus the "distance" created between the corporate shareholders and the strategic and governance 
decisions, which are taken by a skilled Supervisory Board. Even if this model allows to separate the property from the social organs, at the same time, doubts have been raised regarding the independence of the supervisory board (which is responsible for financial statement controls and at the same time is the body responsible for approving it).

About the Supervisory Board, it must be composed of at least three members (partners or not), appointed by the shareholders' assembly and its powers are defined in the by-laws. This board carries out the functions of supervision and control, assuming the same responsibilities provided for the board of statutory auditors (such as the accounting control), and a wide part of the functions of the shareholders assembly. According to the art. 2409terdecies, par. 1, the supervisory board nominates and revokes the members of the management board, approves the financial statement and, where required, the consolidated financial statement. Furthermore, the by-laws may provide that in case of failure to approve the financial statement, the approval is attributed to the shareholders assembly.

In dualistic system, the management board has the same powers of the board of directors, while the supervisory board nominates and revokes the members of the management board and carries out, unless different statutory specifications, the accounting controls. Depending on the statutory regulations, the accounting control may be achieved by an external auditor, in this case, the same applies to the traditional system.

\subsubsection{Independence and critical aspects of dualistic system in Italy}

Given the particular structure of the dualistic model, some rules have been defined by the law, in order to guarantee the independence of the boards. At this purpose, the members of the Supervisory Board cannot be nominated into the Management Board (art. 2409-novies, paragraph 4) and the members of the Management Board cannot be nominated as Supervisory Board members. If during the year is no longer kept the legal number of members of the management board, the supervisory board provides with the substitution (art. 2409-novies, paragraph 6). The members of the Management Board can be reelected, unless differently provided by the by-laws, and they can be revoked by the supervisory board at any time.

As explained above, one of the fundamental characteristics of the dualistic system is that the shareholders assembly, whose tasks are significantly reduced respect to the traditional system, is responsible for the appointment of the members of the Supervisory Board and, in turn, the Supervisory Board, whose main function is to monitor the work of the Management Board, is responsible for the appointment of management board members (Fortunato, 2003; Lener, 2002).

From a functional point of view, therefore, in the traditional system it is the property (the shareholders) that elects both the "controller" (board of statutory auditors) and the "controlled" (directors) and delegates to the latter the company's management. On the other hand, in the dualistic system the property (the shareholders) elects the controllers (supervisory board) and the latter elect the controlled (management board) to whom the management of the company is entrusted. As a consequence, following this mechanism of nomination, the relationship between controllers and controlled has greater interdependence (Consiglio Nazionale dei Dottori Commercialisti e degli Esperti Contabili, 2006).

Another particular characteristic of the dualistic model applied in Italy, is that differently from the dualistic model applied in Germany, to which the Italian legislator was inspired, the Italian administration and control model lack of legislative provision about the appointment of representatives of the workers among the members of the supervisory board (Cottino, Bonfante, Cagnasso, \& Montalenti, 2004; Marchetti, Bianchi, Ghezzi, \& Notari, 2008; Pernazza, 2002). Indeed, in German companies a decisive role is played by the workers and the banks (usually the main shareholders in the companies) in terms of the power to define the composition of the controlling body which, in turn, appoints the board of management (Gandini, Astori, \& Cassano, 2009). As highlighted by De Toni et al. (2011) the German dualistic model applied in Italy failed for at least two main inefficiencies: the first is the inability of companies to correctly adapt to the model; the second is the tendency, inside the corporate governance, to let specific interests of some parties prevail, in doing so nullifying the attempt for a correct adoption.

\subsection{Monistic system}

The monistic system is inspired by the Anglo-Saxon model and, respect to the other two systems, is more flexible. The role of shareholders assembly is the same as seen in the traditional system, with the exception that the body of control - unless differently provided in the by-laws - is appointed by the board of Directors (Figure 3).

Figure 3. Monistic system (own elaboration)

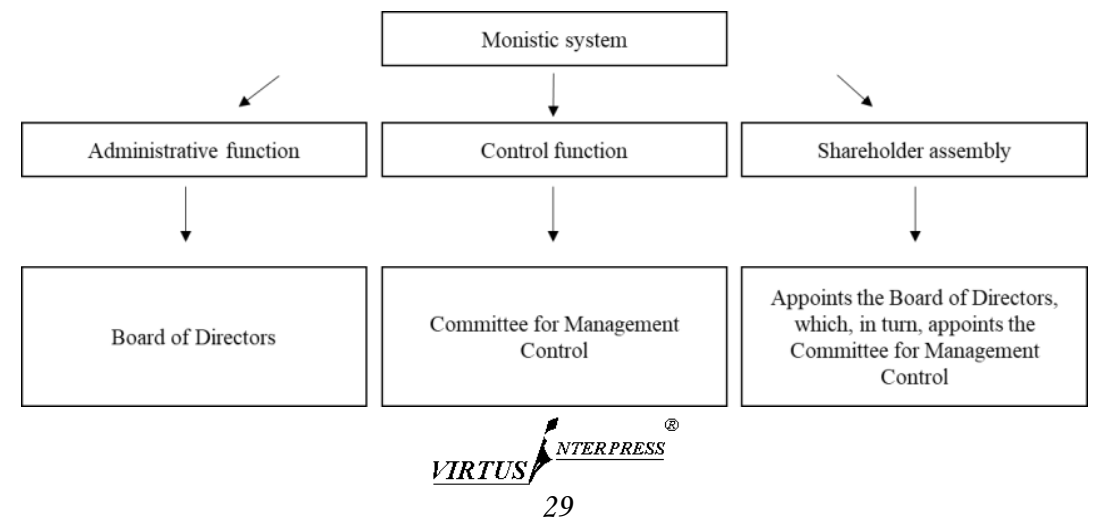


Furthermore, in the monistic model, company management is a task of the board of directors and cannot be assigned to a sole administrator. This board must be composed, for at least one third, by individuals which respect the same independence requisites established for the auditors or - if specified in the company by-laws - the requisites provided by codes of behavior.

The board of directors must appoint a committee for management control, internal to the board itself, for the supervision of management. This committee has the same functions of the board of statutory auditors and thus, it must be composed by members having the same requisites of independence established for the statutory auditors. Furthermore, at least one member must be a certified auditor. As can be seen, the administrative and supervisory functions are attributed to a single organism; this, on one side, can lead to a better information flow and to more prompt corrective actions, but, on the other side, it can compromise the independence of the two bodies, as the "controlled" board appoints the "controller" committee, which, moreover, is internal to the former.

As a matter of fact, the controls on the management board activities may be only attributed to the committee for management control, but this can only be done by the board of Directors, which is the same body subject to control. Hence, in companies adopting the monistic system, there is no body expressly delegated to verify the correct management of the company, nor the respect of the law and the by-laws, aspects on which the members and third parties will have to rely solely on the moral and managerial qualities of the administrators and of the committee members.

In the companies which access the risk capital market, the number of components of the committee cannot be lesser than three, whereas, in "closed" companies it cannot be lesser than two (in both cases, at least one of the members must be a certified auditor).

One aspect that could reduce the criticality of the monistic model is the possibility that the by-laws attributes to the shareholder assembly the task to appoint the committee for management control. In this case, the shareholders would nominate all the members of the board of Directors, included those eligible for being part of the committee for management control.

In other terms, the shareholders assembly retains the same functions established in the classic system and the board of directors has the same powers as in the traditional system. The only difference between the monist model and the others is that the committee for management control must be appointed within the same board of directors.

\section{ANALYSIS OF CORPORATE BOARD PRACTICES IN ITALY}

\subsection{The role of the management and control bodies}

The role of the management and control bodies in the corporate governance may be different according to the administration and control system adopted by the company. In case of classical (or traditional) system, shown above, there is a distinction between the management body (CEO or board of directors) and the Supervisory Board. The 2003 reform has introduced some important new regulations concerning the tasks of the Chairman, the definition of the powers and the duties of the delegated and delegating bodies. Regarding the first point, the role of the Chairman is mainly to guarantee the effective functioning of the board of directors. The Chairman, indeed, shall convene the board of directors, defines its agenda and coordinates the operations, ensuring the availability of the information useful for accomplishing the tasks assigned to the members of the board.

The board of directors (art. 2388, 2392, 2446 Civil Code) may delegate its powers to an executive committee composed of some of its members, or to one or more of its members. The board of directors determines the content, limits and possible methods of exercising the delegation (art. 2405, 2421, n. 6); he can always give directives to the delegated bodies and take on himself operations that are part of the delegation. The 2003 reform indicates the powers and duties of the delegated bodies (such as the managing director and executive committee) compared to the delegating bodies. On the basis of the information received, it assesses the adequacy of the organizational, administrative and accounting structure of the company; when available, it examines the strategic, industrial and financial plans of the company; evaluates, on the basis of the report of the delegated bodies, the general management trend.

On their part, the delegated bodies, as established by the 5th paragraph of art. 2381 Civil Code, must verify that the organizational, administrative and accounting structure is adequate to the nature and size of the company and must report to the board of directors and to the board of Statutory Auditors, with the periodicity established by the by-laws (and in any case at least every six months), on the general management trend, its foreseeable evolution, and on the most significant transactions - that is, the transactions that, due to their size or characteristics, are classifiable as "significant" - carried out by the company and its subsidiaries. Therefore, the essential task of the delegated bodies is to put in place an efficient organization of the company, in every aspect, such as, for example, the internal control system, the administrative and the accounting system, the organization of information flows from the subsidiaries.

On one side, thus, the delegated bodies have the duty to inform the board of directors to keep it updated on the business management and, on the other side, the directors must act in an informed way, even asking information when required, as they have to analytically motivate their decisions, supporting them with reliable and updated information.

Another consideration regarding the Law $99 / 2003$ is that the reform provides duties of the delegated bodies clearly distinct from those of the directors without delegation. This distinction is reflected in the respective responsibilities. Although the principle of joint liability of the directors has been preserved, the position of each of the various parties jointly responsible must be assessed in 
relation to the different obligations that they are responsible for.

\subsection{The Role of the Chairman}

The art. 2381 of the Civil Code states that unless otherwise indicated in the bylaws, the chairman convenes the board of directors, defines the agenda and coordinates the activities, ensuring that the members of the board receive adequate information regarding the agenda items. The Chairman is appointed by the board of directors or by the assembly of shareholders. The chairman of the board, especially in the larger companies, can be assisted by one or more vice presidents.

\subsection{Women on the boardrooms}

Several European countries have passed legislation mandating more female directors in the boardroom, since women are under-represented in the boardrooms throughout companies in Europe.

For example, in the UK, the Higgs report (Higgs, 2003) argues that diversity within a firm could improve the effectiveness of the corporate governance board (R. B. Adams \& Ferreira, 2009). In Sweden gender diversity is a legal requirement (Medland, 2004). In Norway, since 2008 all listed companies must have a $40 \%$ of female directors.

In the Italian context, the Law 120/2011 ("Law 120") and Consob No. 18098/2012 introduced the gender quotas on boards. In particular, Law 120 was a news in the Italian legislation, since it introduced the gender diversity awareness in the Italian legal system, thereby introducing "quote rosa", i.e. "pink quotas" for women in listed companies. The Law 120 requires that all Italian listed firms reserve one third of the directors positions to the under-represented gender in the boardrooms. This law has a 10-year validity; during this time, women in the boardrooms of the Italian listed firms may affirm their skills and contribute to the creation of value. The main aim of this new legislation is to overcome the topic of the gender diversity within the firms and the economy in general, by delating the obstacles that prevented the active participation of women on the powerful position within a firm.

\section{ANALYSIS OF A LINK BETWEEN BOARD GOVERNANCE AND COMPANY PERFORMANCE}

The features of the board governance have been deeply investigated by several scholars during the last decades. Prior literature focused on some characteristics such as the number of board of directors, the diversity in the boardroom, the composition of the board among outsider and independent directors, family ties and interlocking directors, the structure of the board committees, the frequency of meetings and the relationship between these features of board governance and company performance.

Empirical research on the link between features of corporate governance and company performance are mainly based on the agency theory (Azeez, 2015; Jensen \& Meckling, 1976). As a matter of fact, agency theory suggests that firms with a better corporate governance should have better financial and economic performance due to lower agency costs (Azeez, 2015). Indeed, Gompers et al. (2003) found a positive relationship between corporate performance in terms of Tobin's Q and corporate governance and other scholars found similar results by measuring firm performance in terms of Return on Equity (ROE), Return on Assest (ROA) as well as Tobin's Q (Brown \& Caylor, 2009). Other theories that literature use to analyse the link between board governance and firm performance are the resource-based theory (Barney \& Mackey, 2016) and the upper echelons theory (Hambrick \& Mason, 1984). The former states that company performance can vary according to different skills and resources that can be linked to different features of the board structure, whereas the latter argues that the background and experiences of top directors at the "upper echelons" affects the way in which they can make strategic decision.

Many recent studies on the relationship between board governance and company performance have been carried out with different aims: for example, Fuzi et al. (Fuzi, Halim, \& Julizaerma, 2016) investigate the board independence and the firm performance; Arora and Sharma (Arora \& Sharma, 2016) analyse the relations between corporate governance and firm performance in India; Fernández-Gago et al. (Fernández-Gago, Cabeza-García, \& Nieto, 2016) analyse the influence of corporate social responsibility and board of directors on firm performance in Spain; Nkundabanyanga (2016) includes also the intellectual capital effect in the study of board governance and firm performance; Duru et al. (Duru, Iyengar, \& Zampelli, 2016) analyse the dynamic relationship between CEO duality and firm performance.

In the Italian setting, very few contributions analyse the relationship between corporate governance and firm performance (Bianco \& Casavola, 1999). In particular, Culasso et al. (2012) compared family and non-family firms, by focusing on the effects that the board composition have on the firm performance. Scholars found that the family role has a positive impact on the corporate performance and that the structure of the board has effects on the firm performance, even if the percentage of independent members in Italy is not relevant (Culasso et al., 2012) - see Table 1.

Table 1. Literature review on the link between board governance and company performance

\begin{tabular}{|l|l|l|}
\hline Theoretical background & \multicolumn{1}{|c|}{ Scholars } & \multicolumn{1}{c|}{ Main findings } \\
\hline & $\begin{array}{l}\text { Azeez 2015, Gompers et al. } \\
\text { 2003; Carter et al. 2003; }\end{array}$ & $\begin{array}{l}\text { - Firms with a better corporate governance should have better financial and } \\
\text { economic performance due to lower agency costs. }\end{array}$ \\
$\begin{array}{l}\text { - Agency theory } \\
\text { - Resource-based theory } \\
\text { - Upper echelons theory and Caylor 2009; } \\
\text { Culasso et al. 2012; Bianco } \\
\text { and Casavola 1999 }\end{array}$ & $\begin{array}{l}\text { The background linked to different features of the board structure. } \\
\text { affects the way in which they can make strategic decision. }\end{array}$ \\
\hline
\end{tabular}




\subsection{Gender diversity and firm performance}

Within this framework, a recent and open debate regards the introduction of gender minority in the board of directors and its effects on the overall performance and the reputation of a company (Campbell \& Mínguez-Vera, 2008; Green \& Homroy, 2018; Francoeur, Labelle, Balti, \& Bouzaidi, 2019). Previous literature about this topic focused on the different kinds of diversity, such as gender, racial and culture ones, which may have some effects on the firm value (Carter, Simkins, \& Simpson, 2003), by confirming the relevance of the composition of the board of directors. However, the topic is quite controversial. Indeed, some scholars found that diversity has positive impacts, whereas others found the opposite and finally others did not find any significantly association between the diversity in the boardroom and the firm performance. With regard to the former viewpoint, scholars found that corporate diversity may produce more effective problem-solving due to the variety of perspectives and to an increase in creativity and innovations (Robinson \& Dechant, 1997). Furthermore, diversity tends to promote more effective global relationships in an international environment (Carter et al., 2003).

Several studies focused on the relationship between the percentage of female members of boards and several measures of firm performance (Robinson \& Dechant, 1997).

Some scholars highlighted the benefits on the corporate social responsibility control of having female directors, since they are they are more participative (Eagly \& Carli, 2003) and democratic than men (Eagly \& Johnson, 1990), whereas men are mainly money oriented (Huse, Nielsen, \& Hagen, 2009). Other scholars found that women in the topmanagement positions may have positive impacts on the corporate governance, since they seem to have less attendance problems than men. Furthermore, female directors do not belong to the "old boys club", therefore they might be more closed to the concept of the independent director (R. B. Adams \& Ferreira, 2009). Other studies found that females are often appointed by companies with the aim to reduce the overall risk of the firm (Martin, Nishikawa, \& Williams, 2009) since females are perceived more risk-averse than males (Atkinson,
Kaplan, \& Young, 2004; Lee \& James, 2007; Oakley, 2000)

Others demonstrated that some measures of company performance, such as Tobin's Q and Return On Assets (ROA), are positively correlated to the percentage of women on the boardrooms (R. Adams \& Ferreira, 2003; Campbell \& Mínguez-Vera, 2008; Nekhili \& Gatfaoui, 2013; Terjesen, Couto, \& Francisco, 2015).

Other scholars found that women are able to offer fresh solutions to complex issues, thereby helping correct informational bias in strategy formulation and problem solving (Francoeur, Labelle, \& Sinclair-Desgagne, 2008). Virtanen (2012) demonstrated that female directors are more likely to cover active roles compared to their male colleagues (Virtanen, Malmi, Vaivio, \& Kasanen, 1996) and others provided empirical evidence that female directors are more likely to have debate than male managers and have leadership and collaborative skills (Eagly \& Johnson, 1990; Ingley \& Van Der Walt, 2005). Muller-Kahle and Lewellyn (2011) found that gender diversity within the corporate board may have positive impacts on the overall firm operations, especially when risky strategic decisions are to be evaluated (Muller-Kahle \& Lewellyn, 2011). Gul et al. (2011) demonstrated a positive relationship between gender diversity and stock price informativeness due to an increased voluntary disclosure (Gul, Srinidhi, \& Ng, 2011).

Furthermore, Gregory et al. (2013) demonstrated that, in the long term, the market is able to recognize the positive effect of the female directors on corporate performance, whereas in the short term, market tends to underrate this positive effect (Gregory, Jeanes, Tharyan, \& Tonks, 2013).

Other scholars found opposite results with this regard. In particular some scholars found a negative link or did not find any types of relationship between firm performance and female directors (Zahra \& Stanton, 1988). Ola and Proffitt (2015) argue that women and men are perceived in the same way by the investors, since they found that the gender of a fired CEO has no impact on stock price (Ola \& Proffitt, 2015). Some scholars found that companies perform worse if they have a greater gender diversity of their corporate board (Shrader, Blackburn, \& Iles, 1997).

Table 2. Literature review on the link between gender diversity and company performance

\begin{tabular}{|c|c|c|}
\hline Literature streams & Scholars & Main findings \\
\hline $\begin{array}{l}\text { Positive link between } \\
\text { the gender diversity } \\
\text { and company } \\
\text { performance }\end{array}$ & $\begin{array}{l}\text { Robinson and Dechant 1997; Carter et al. } \\
\text { 2003; Eagly and Carli 2003; Eagly and } \\
\text { Johnson 1990; Huse et al. 2009; Adams } \\
\text { and Ferreira 2009; Martin et al. 2009; } \\
\text { Oakley 2000; Atkinson et al. 2004; Lee } \\
\text { and James 2007; Adams and Ferreira } \\
\text { 2003; Campbell and Mínguez-Vera 2008; } \\
\text { Nekhili and Gatfaoui 2013; Terjesen et } \\
\text { al. 2015; } \\
\text { Francoeur et al. 2008; Eagly and Johnson 1. }\end{array}$ & $\begin{array}{l}\text { - Corporate diversity may produce more effective problem-solving } \\
\text { due to the variety of perspectives and to an increase in creativity } \\
\text { and innovations; } \\
\text { - Female directors are more participative (Eagly \& Carli, 2003) and } \\
\text { democratic than men; } \\
\text { - Female directors do not belong to the "old boys club", therefore } \\
\text { they might be more closed to the concept of the independent } \\
\text { director: } \\
\text { - Some measures of company performance are positively correlated } \\
\text { to the percentage of women on the boardrooms. }\end{array}$ \\
\hline $\begin{array}{l}\text { Negative link between } \\
\text { the gender diversity } \\
\text { and company } \\
\text { performance }\end{array}$ & Shrader et al. 1997 & $\begin{array}{l}\text { - Companies perform worse if they have a greater gender diversity } \\
\text { of their corporate board. }\end{array}$ \\
\hline $\begin{array}{l}\text { Any link between the } \\
\text { gender diversity and } \\
\text { company performance }\end{array}$ & $\begin{array}{l}\text { Ola and Proffitt 2015; di Donato et al. } \\
2016\end{array}$ & $\begin{array}{l}\text { - Women and men are perceived in the same way by the investors, } \\
\text { since they found that the gender of a fired CEO has no impact on } \\
\text { stock price; } \\
\text { - No correlation between the percentage of women in the } \\
\text { boardrooms and the corporate performance in terms of Tobin's Q } \\
\text { after the introduction of the Law } 120 \text { in the Italian setting. }\end{array}$ \\
\hline
\end{tabular}


With this regard, di Donato et al. (2016) found that no company has more than four female directors, even if the percentage of female directors increased in 2013 after the introduction of the Law 120 in the Italian context. However, they came to mixed results about the link between company performance and the diversity in the boardroom of Italian listed firm. In particular, they did not find no correlation between the percentage of women in the boardrooms and the corporate performance in terms of Tobin's Q after the introduction of the Law 120, and, on the opposite, they found a negative correlation between female directors and firm performance in terms of ROA (Return on Assets) after the introduction of the Law 120 - see Table 2.

\subsection{Network among directors and firm performance}

Socio-cognitive studies discusses the relevance of directors' network among different boardrooms in having the best strategic knowledge useful for the decision making process in companies, since directors may use skills and knowledge acquired in similar experiences (Carpenter \& Westphal, 2001; Walsh, 1995). Some advantages due to networks among directors of different firms are the possibility that directors may obtain private information through their external networks (Stiles, 2001); the development of inter-organizational relationships (Zahra \& Stanton, 1988) and the reduction incentives for opportunism by enhancing mutual flow of information between exchange partners (Kaczmarek, Kimino, \& Pye, 2014). To our best knowledge, few contributions are carried out on this topic within the Italian setting (Drago, Manestra, \& Santella, 2011). With this regard, di Donato et al. (2016) found a positive correlation between financial performance of Italian listed firms and the connections among directors on different boardrooms.

\section{CONCLUSION}

Corporate governance in Italy is a largely debated topic even among practitioners and received significant attention by regulators and mass media. With regard to the link between company performance and the features of the board, we can conclude that most of the literature found a positive link between some measures of firm performance and board governance on the basis of the agency theory, the resource-based theory and the upper echelons theory. If we focus on the gender diversity among directors, most of scholars found a positive link between the presence of female directors and some measures of firm performance, whereas few scholars found a negative link or did not find any types of relationship between firm performance and female directors. In the Italian setting, some authors did not find any correlation between the percentage of women in the boardrooms and the corporate performance in terms of Tobin's $\mathrm{Q}$ after the introduction of the Law 120, and, on the opposite, the same authors found a negative correlation between female directors and firm performance in terms of ROA (Return on Assets) after the introduction of the Law 120. However, literature argues that connections among directors on different boardrooms are very relevant for increasing the financial performance of firms.

In Italy, firms can choose among three different systems of corporate governance: traditional, monistic and dualistic. Differently from the monistic and the dualistic system, the traditional system is adopted in absence of a different statutory choice of the company.

The main limitation of this research is related to the nature of the study, which is focused on the analysis of the governance models of a single country, Italy, making it difficult to extend the results to other contexts. Furthermore, despite this study is strongly based on the literature review, thus representing significantly what emerges from the doctrine, an empirical investigation would provide further outcomes and clues for a deeper examination.

Therefore, further research may focus on the following topics: 1) the empirical analysis of the effects of the different features of the board on the firm performance in Italian listed and non-listed firms, by highlighting the potential differences between the two different types of firms; 2) the empirical analysis of the effects of the different features of directors on the firm performance in Italian family and non-family firms, by identifying the potential differences between the two different types of firms; 3 ) the empirical analysis of classic, monistic and dualistic systems, to study the possible relationships between the corporate governance model and the companies' performance in different industries.

To shed some light on these topics, it could be useful to submit a questionnaire to the top managers of different types of firms. As a matter of fact, until now, most of the literature on this topic is based on data collected from public databases, e.g. Thomson Reuters Datastream.

\section{REFERENCES}

1. Adams, R. B., \& Ferreira, D. (2009). Women in the boardroom and their impact on governance and performance. Journal of Financial Economics, 94(2), 291-309. https://doi.org/10.1016/j.jfineco.2008.10.007

2. Adams, R., \& Ferreira, D. (2003). Diversity and incentives: evidence from corporate boards. Working Paper, University of Stockholm. Retrieved from http://papers.ssrn.com/sol3/Delivery.cfm?abstractid=321095

3. Airoldi, G. (1993). Modelli di capitalismo e modelli di impresa. Schemi per l'analisi comparata. Economia \& Management, 64-79.

4. Arora, A., \& Sharma, C. (2016). Corporate governance and firm performance in developing countries: Evidence from India. Corporate Governance, 16(2), 420-436. https://doi.org/10.1108/CG-01-2016-0018

5. Atkinson, A. A., Kaplan, R. S., \& Young, S. M. (2004). Management Accounting, 4th ed. New Jersey: Pearson Prentice.

6. Azeez, A. A. (2015). Corporate governance and firm performance: Evidence from Sri Lanka. Journal of Finance, 3(1), 180-189. https://doi.org/10.15640/jfbm.v3n1a16 
7. Barker, R. M. (2010). Corporate governance, competition, and political parties: explaining corporate governance change in Europe. Oxford University Press on Demand. https://doi.org/10.1093/acprof:oso /9780199576814.001.0001

8. Barney, J. B., \& Mackey, A. (2016). Text and metatext in the resource-based view. Human Resource Management Journal, 26(4), 369-378. https://doi.org/10.1111/1748-8583.12123

9. Bianco, M., \& Casavola, P. (1999). Italian corporate governance: Effects on financial structure and firm performance. European Economic Review, 43(4), 1057-1069. https://doi.org/10.1016/S0014-2921(98)00114-7

10. Brown, L. D., \& Caylor, M. L. (2009). Corporate governance and firm operating performance. Review of Quantitative Finance and Accounting, 32(2), 129-144. https://doi.org/10.1007/s11156-007-0082-3

11. Buonocore, V., Bassi, A., \& Pescatore, S. (2003). La riforma del diritto societario: commento ai D. lgs. $n$. 5-6 del 17 gennaio 200. Giappichelli. Retrieved from https://scholar.google.it/scholar?hl=it\&as_sdt=0\%2C5\&q= Buonocore\%2C+V.\%2C+Bassi\%2C+A.\%2C+\%26+Pescatore\%2C+S.+\%282003\%29.+La+riforma+del+diritto+societari o\%3A+commento+ai+D.+lgs.+n.+5-6+del+17+gennaio+2003.+Giappichelli.\&btnG=

12. Calabrò, A., Campopiano, G., \& Basco, R. (2017). Principal-principal conflicts and family firm growth: The moderating role of business family identity. Journal of Family Business Management, 7(3), 291-308. https://doi.org/10.1108/JFBM-02-2017-0005

13. Campbell, K., \& Mínguez-Vera, A. (2008). Gender diversity in the boardroom and firm financial performance. Journal of Business Ethics, 83(3), 435-451. https://doi.org/10.1007/s10551-007-9630-y

14. Carpenter, M. A., \& Westphal, J. D. (2001). The strategic context of external network ties: Examining the impact of director appointments on board involvement in strategic decision making. Academy of Management Journal, 44(4), 639-660. https://doi.org/10.2307/3069408

15. Carter, D. A., Simkins, B. J., \& Simpson, W. G. (2003). Corporate governance, board diversity, and firm value. Financial Review, 38(1), 33-53. https://doi.org/10.1111/1540-6288.00034

16. Consiglio Nazionale dei Dottori Commercialisti e degli Esperti Contabili. (2006). Documento 60. Fondazione Aristeia. Retrieved from http://www.fondazionenazionalecommercialisti.it/system/files/imce/areetematiche/ari/docari60 b.pdf

17. Cottino, G., Bonfante, G., Cagnasso, O., \& Montalenti, P. (2004). Il nuovo diritto societario, Commentario. Bologna: Zanichelli (Italy).

18. Culasso, F., Broccardo, L., Mazzoleni, A., \& Giacosa, E. (2012). Corporate governance in listed Italian family firms: Impact on performance and comparison with non-family firms. Journal of Management \& Change, 29(1), $67-88$.

19. De Toni, A., Magli, F., \& Nobolo, A. (2011). When the dualistic system doesn't facilitate governance. Reflections on the Mediobanca case. Giuffrè Editore.

20. Di Donato, F., Panaro, D., \& Trucco, S. (2016). Board gender diversity, network and firms' performance in the Italian listed companies. International Journal of Business and Management, 11(10), 332. https://doi.org/10.5539/ijbm.v11n10p332

21. Di Sabato, F. (2011). Diritto delle società. Giuffrè editore.

22. Drago, C., Manestra, S., \& Santella, P. (2011). Interlocking directorships and cross-shareholdings among Italian blue chips. European Business Organization Law Review, 12(4), 619-652. https://doi.org/10.1017/ S1566752911400045

23. Drago, C., Millo, F., Ricciuti, R., \& Santella, P. (2015). Corporate governance reforms, interlocking directorship and company performance in Italy. International Review of Law and Economics, 41, 38-49. https://doi.org/10.1016/j.irle.2014.09.003

24. Dyck, A., \& Zingales, L. (2004). Private benefits of control: An international comparison. The Journal of Finance, 59(2), 537-600. https://doi.org/10.1111/j.1540-6261.2004.00642.x

25. Duru, A., Iyengar, R. J., \& Zampelli, E. M. (2016). The dynamic relationship between CEO duality and firm performance: The moderating role of board independence. Journal of Business Research, 69(10), 4269-4277. https://doi.org/10.1016/j.jbusres.2016.04.001

26. Eagly, A. H., \& Carli, L. L. (2003). Finding gender advantage and disadvantage: Systematic research integration is the solution. The Leadership Quarterly, 14(6), 851-859. https://doi.org/10.1016/j.leaqua.2003.09.003

27. Eagly, A. H., \& Johnson, B. T. (1990). Gender and leadership style: A meta-analysis. Psychological Bulletin, 108(2), 233. https://doi.org/10.1037/0033-2909.108.2.233

28. Elshandidy, T., \& Neri, L. (2015). Corporate governance, risk disclosure practices, and market liquidity: Comparative evidence from the UK and Italy. Corporate Governance: An International Review, 23(4), 331-356. https://doi.org/10.1111/corg.12095

29. Estwick, S. (2016). Principal-principal agency and financial flexibility in transition economies. The Journal of Business Inquiry, 15(1), 33-54.

30. Fernández-Gago, R., Cabeza-García, L., \& Nieto, M. (2016). Corporate social responsibility, board of directors, and firm performance: an analysis of their relationships. Review of Managerial Science, 10(1), 85-104. https://doi.org/10.1007/s11846-014-0141-9

31. Fortunato, S. (2003). I "controlli" nella riforma del diritto societario. Rivista delle società, 872.

32. Francoeur, C., Labelle, R., \& Sinclair-Desgagne, B. (2008). Gender diversity in corporate governance and top management. Journal of Business Ethics, 81(1), 83-95. https://doi.org/10.1007/s10551-007-9482-5

33. Francoeur, C., Labelle, R., Balti, S., \& Bouzaidi, S. E. (2019). To what extent do gender diverse boards enhance corporate social performance? Journal of Business Ethics, 1-15.

34. Fuzi, S. F. S., Halim, S. A. A., \& Julizaerma, M. K. (2016). Board independence and firm performance. Procedia Economics and Finance, 37, 460-465. https://doi.org/10.1016/S2212-5671(16)30152-6

35. Galgano, F., \& Genghini, R. (2004). Trattato di diritto commerciale e di diritto pubblico dell'economia: Il nuovo diritto societario. Gli statuti delle nuove società di capitali. Cedam (Italy).

36. Gandini, G., Astori, R., \& Cassano, R. (2009). Structures of corporate governance in Italy and comparison at European level. International Review of Business Research Papers, 5(1), 441-453.

37. Gompers, P., Ishii, J., \& Metrick, A. (2003). Corporate governance and equity prices. The Quarterly Journal of Economics, 118(1), 107-156. https://doi.org/10.1162/00335530360535162

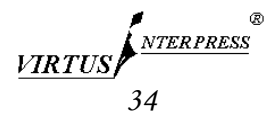


38. Green, C. P., \& Homroy, S. (2018). Female directors, board committees and firm performance. European Economic Review, 102, 19-38. https://doi.org/10.1016/j.euroecorev.2017.12.003

39. Gregory, A., Jeanes, E., Tharyan, R., \& Tonks, I. (2013). Does the stock market gender stereotype corporate boards? Evidence from the market's reaction to directors' trades. British Journal of Management, 24(2), 174190. https://doi.org/10.1111/j.1467-8551.2011.00795.x

40. Gul, F. A., Srinidhi, B., \& Ng, A. C. (2011). Does board gender diversity improve the informativeness of stock prices? Journal of Accounting and Economics, 51(3), 314-338. https://doi.org/10.1016/j.jacceco.2011.01.005

41. Hambrick, D. C., \& Mason, P. A. (1984). Upper echelons: The organization as a reflection of its top managers. Academy of Management Review, 9(2), 193-206. https://doi.org/10.5465/AMR.1984.4277628

42. Higgs, D. (2003). Review of the role and effectiveness of non-executive directors. DTI London. Retrieved from http://www.opengrey.eu/item/display/10068/464374

43. Huse, M., Nielsen, S. T., \& Hagen, I. M. (2009). Women and employee-elected board members, and their contributions to board control tasks. Journal of Business Ethics, 89(4), 581-597. https://doi.org/10.1007/s10551-008-0018-4

44. Ingley, C., \& Van Der Walt, N. (2005). Do board processes influence director and board performance? Statutory and performance implications. Corporate Governance: An International Review, 13(5), 632-653. https://doi.org/10.1111/j.1467-8683.2005.00456.x

45. Jensen, M. C., \& Meckling, W. H. (1976). Theory of the Firm: Managerial behavior, agency costs, and ownership structure. In K. Brunner (Ed.), Economics Social Institutions (pp. 163-231). Springer Netherlands. Retrieved from http://link.springer.com/chapter/10.1007/978-94-009-9257-3_8

46. Kaczmarek, S., Kimino, S., \& Pye, A. (2014). Interlocking directorships and firm performance in highly regulated sectors: The moderating impact of board diversity. Journal of Management \& Governance, 18(2), 347-372. https://doi.org/10.1007/s10997-012-9228-3

47. Lee, P. M., \& James, E. H. (2007). She'-e-os: Gender effects and investor reactions to the announcements of top executive appointments. Strategic Management Journal, 28(3), 227-241. https://doi.org/10.1002/smj.575

48. Lener, R. (2002). Appunti sull'organo di sorveglianza delle società per azioni nelle proposte di legge delega sulla riforma delle società non quotate. In AA.VV. (a cura di Associazione Disiano Preite), Verso un nuovo diritto societario, 197, Bologna: Il Mulino (Italy).

49. Marchetti, P., Bianchi, L. A., Ghezzi, F., \& Notari, M. (2008). Commentario alla riforma delle società. EGEA: Giuffrè.

50. Martin, A. D., Nishikawa, T., \& Williams, M. A. (2009). CEO gender: Effects on valuation and risk. Quarterly Journal of Finance and Accounting, 23-40.

51. Medland, D. (2004). Small steps for womankind. Corporate Board Member Europe, Winter.

52. Melis, A. (2000). Corporate governance in Italy. Corporate Governance: An International Review, 8(4), 347-355. https://doi.org/10.1111/1467-8683.00213

53. Melis, A., \& Zattoni, A. (2017). A Primer on Corporate Governance: Italy. Business Expert Press.

54. Muller-Kahle, M. I., \& Lewellyn, K. B. (2011). Did board configuration matter? The case of US subprime lenders. Corporate Governance: An International Review, 19(5), 405-417. https://doi.org/10.1111/j.14678683.2011.00871.x

55. Nekhili, M., \& Gatfaoui, H. (2013). Are demographic attributes and firm characteristics drivers of gender diversity? Investigating women's positions on French boards of directors. Journal of Business Ethics, 118(2), 227-249. https://doi.org/10.1007/s10551-012-1576-z

56. Nkundabanyanga, S. K. (2016). Board governance, intellectual capital and firm performance: Importance of multiplicative effects. Journal of Economic and Administrative Sciences, 32(1), 20-45. https://doi.org/10.1108/JEAS-09-2014-0020

57. Oakley, J. G. (2000). Gender-based barriers to senior management positions: Understanding the scarcity of female CEOs. Journal of Business Ethics, 27(4), 321-334. https://doi.org/10.1023/A:1006226129868

58. Ola, J. C., \& Proffitt, D. (2015). The stock market response to CEO changes: Does gender matter? International Journal of Business and Management, 10(5), 1. https://doi.org/10.5539/ijbm.v10n5p1

59. Pernazza, F. (2002). Il conseil de surveillance della société anonyme nell'esperienza francese. In AA.VV. (a cura di Associazione Disiano Preite). Verso un nuovo diritto societario (pp. 205-212). Bologna: Il Mulino (Italy)

60. Robinson, G., \& Dechant, K. (1997). Building a business case for diversity. The Academy of Management Executive, 11(3), 21-31. https://doi.org/10.5465/ame.1997.9709231661

61. Shrader, C. B., Blackburn, V. B., \& Iles, P. (1997). Women in management and firm financial performance: An exploratory study. Journal of Managerial Issues, 355-372.

62. Stiles, P. (2001). The impact of the board on strategy: An empirical examination. Journal of Management Studies, 38(5), 627-650. https://doi.org/10.1111/1467-6486.00252

63. Sun, J., Yuan, R., Cao, F., \& Wang, B. (2017). Principal-principal agency problems and stock price crash risk: Evidence from the split-share structure reform in China. Corporate Governance: An International Review, 25(3), 186-199. https://doi.org/10.1111/corg.12202

64. Terjesen, S., Couto, E. B., \& Francisco, P. M. (2015). Does the presence of independent and female director's impact firm performance? A multi-country study of board diversity. Journal of Management \& Governance, 137.

65. Venturi, C. (2008). I modelli di amministrazione e controllo nelle società di capitali. In Tuttocamere (pp. 1-30).

66. Virtanen, K., Malmi, T., Vaivio, J., \& Kasanen, E. (1996). Drivers of management accounting in Finland. Management Accounting: European Perspectives, 54-73.

67. Walsh, J. P. (1995). Managerial and organizational cognition: Notes from a trip down memory lane. Organization Science, 6(3), 280-321. https://doi.org/10.1287/orsc.6.3.280

68. Zahra, S. A., \& Stanton, W. W. (1988). The implications of board of directors composition for corporate strategy and performance. International Journal of Management, 5(2), 229-236.

69. Zattoni, A. (1999). The structure of corporate groups: The Italian case. Corporate Governance: An International Review, 7(1), 38-48. https://doi.org/10.1111/1467-8683.00127

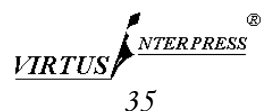

